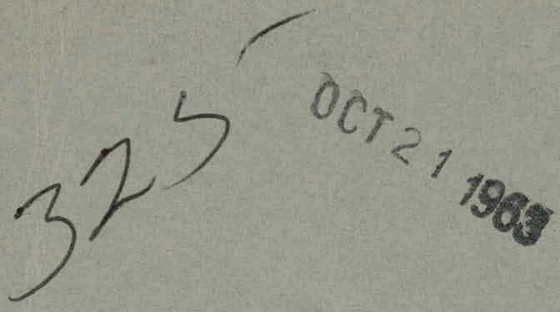

$$
\begin{gathered}
\text { ORNL-3474 } \\
\text { UC-4-Chemistry } \\
\text { TID }-4500 \text { (22nd ed.) }
\end{gathered}
$$

CORROSION OF STAINLESS STEEL IN ACIDIC

NITRATE WASTE SOLUTIONS FROM PROCESSING

STAINLESS STEEL REACTOR FUELS

D. N. Hess

L. Rice

B. Willis

E. S. Snavely

W. E. Clark

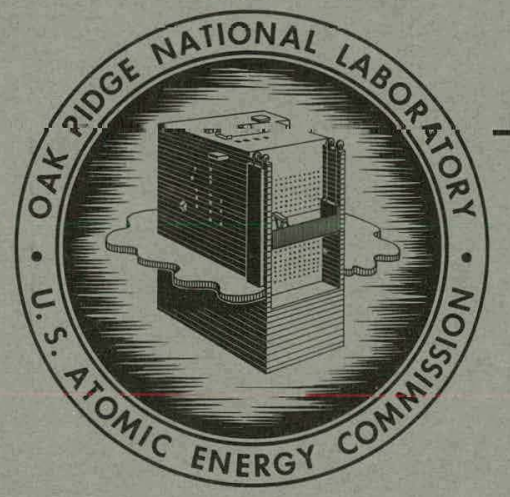

OAK RIDGE NATIONAL LABORATORY operated by UNION CARBIDE CORPORATION for the

U.S. ATOMIC ENERGY COMMISSION 


\section{DISCLAIMER}

This report was prepared as an account of work sponsored by an agency of the United States Government. Neither the United States Government nor any agency Thereof, nor any of their employees, makes any warranty, express or implied, or assumes any legal liability or responsibility for the accuracy, completeness, or usefulness of any information, apparatus, product, or process disclosed, or represents that its use would not infringe privately owned rights. Reference herein to any specific commercial product, process, or service by trade name, trademark, manufacturer, or otherwise does not necessarily constitute or imply its endorsement, recommendation, or favoring by the United States Government or any agency thereof. The views and opinions of authors expressed herein do not necessarily state or reflect those of the United States Government or any agency thereof. 


\section{DISCLAIMER}

Portions of this document may be illegible in electronic image products. Images are produced from the best available original document. 
Printed in USA. Price: $\$ 0.75$ Available from the

Office of Technical Services

U. S. Department of Commerce

Washington 25, D. C

\section{LEGAL NOTICE}

This report was prepared as an account of Government spansored work. Neither the United States, nor the Commission, nor any person acting on behalf of the Commission:

A. Makes any warranty or representation, expressed or implied, with respect to the accuracy, completeness, or usefulness of the information contained in this report, or that the use of any information, apparatus, method, or process disclosed in this report may not infringe privately owned rights; or

B. Assumes any liabilities with respect to the use of, or for damages resulting from the use of any information, apparatus, method, or process disclosed in this report.

As used in the above, "person acting on behalf of the Commission" includes any employee or contractor of the Commission, or employee of such contractor, to the extent that such employee or contractor of the Commission, or employee of such contractor prepares, disseminates, or provides access to, any information pursuant to his employment or contract with the Commission, or his employment with such contractor. 
Contract No. W-7405-eng-26

\author{
CHEMICAL TECHNOLOGY DIVISION \\ Chemical Development Section B \\ and \\ REACTOR CHEMISTRY DIVISION
}

CORROSION OF STAINLESS STEEL IN ACIDIC NITRATE WASTE SOLU-

TIONS FROM PROCESSING STAINLESS STEEL REACTOR FUELS

D. N. Hess, L. Rice, B. Willis, E. S. Snavely, and W. E. Clark

Technician: B. L. Johnson

DA'L'E' 'LS'S'LU'D

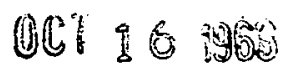

OAK RIDGE NATIONAL LABORATORY

Oak Ridge, Tennessee

operated by

UNION CARBIDE CORPORATION

for the

U. S. ATOMIC ENERGY COMMISSION 


\section{THIS PAGE}

\section{WAS INTENTIONALLY LEFT BLANK}


-iii-

CONTENTS

Page

ABSTRACT . . . . . . . . . . . . . . . . . . . 1

1. INTRODUCTION . . . . . . . . . . . . . . 1

2. EXPERTMENTAL . . . . . . . . . . . . . . 2

3. RESULTS . . . . . . . . . . . . . . 3

4. CONCLUSIONS . . . . . . . . . . . . . 26

5. ACKNOWLEDGMENT . . . . . . . . . . . . . . . 27

6. REFERENCES . . . . . . . . . . . . . . . 28 


\title{
CORROSION OF STATNIESS STEEL IN ACIDIC NITRATE WASTE SOLU- TIONS FROM PROCESSING STAINLESS STEEL REACTOR FUELS
}

\author{
D. N. Hess, L. Rice, B. Willis, E. S. Snavely, and W. E. Clark \\ Technician: B. L. Johnson
}

\begin{abstract}
,
Stainless steel tanks appear to be useful for long-term containment of acid wastes from the reprocessing of stainless steel fuel elements provided that the temperature of the container is kept $\leqq 50^{\circ} \mathrm{C}$ and that tanks are constructed so as not to expose grain ends to the solution.

Chloride ions up to about $0.02 \mathrm{M}$ and fluoride up to about $0.04 \mathrm{M}$ produced no accelerating effect on the corrosion. Certain organic compounds, for example, glycerol, acted as corrosion inhibitors, as did nitrite. Ferric iron in high concentrations was responsible for a grainboundary attack that increased in rate with increase in temperature and with increase in free acid concentration. Catastrophic end-grain attack was ohserved under the most aggressive conditions. In the usual case, true intergranular attack did not develop even after exposure times of $7000 \mathrm{hr}$. The presence of $\mathrm{Cr}$ (III) appeared to accelerate the attack, but only when $\mathrm{Fe}$ (III) was also present. Polarization studies indicated that neither anodic nor cathodic protection would be markedly helpful. Appreciable concentrations of $\mathrm{Cr}(\mathrm{VI})$ were shown to be absent from the solution at temperatures as high as $80^{\circ} \mathrm{C}$. Radiolysis of these solutions is expected to produce corrosion inhibitors (e.g. $\mathrm{NO}, \mathrm{NO}_{2}, \mathrm{H}_{2} \mathrm{O}_{2}$ ) rather than accelerators.
\end{abstract}

\section{INTRODUCTION}

The development of nuclear power plants will, of necessity, be accompanied by the production of large quantities of high-level radioactive wastes. The impossibility of achieving complete burnup of the fissionable material in one pass through the reactor necessitates procedures for recovering and recycling the fissionable materials and for safe disposal of wastes to prevent contamination of the biosphere.

The great majority of research and production reactors employ fuel consisting of uranium, uranium alloys, or $\mathrm{UO}_{2}$ clad with aluminum. The common reprocessing schemes have all involved dissolution of the fuel in nitric acid and solvent extraction of the uranium from the nitrate solution. Consequently, the technology of solvent extraction from these solutions is well developed. Their application to the reprocessing of stainless steel fuels to be used in civilian power reactors requires relatively minor changes in operating procedures and in existing equipment once a ritrate solution of the fuel has been prepared. Dissolution can be accomplished either by anodization of the fuel elements in nitric 
acid ${ }^{-4}$ or by chemical dissolution in mixed nitric and hydrochloric acid followed by removal of the chloride from the solution (Darex Process). 5 In either case the waste solution after feed adjustment and solvent extraction consists of stainless steel dissolved in nitric acid containing at most 200 to $300 \mathrm{ppm}$ of chloride ion. The concentration of free acid in the waste solution may vary from abolut 1 to $5 \mathrm{M}$. Dissolution of fuels containing appreciable amounts of thoria requires the addition of small amounts of fluoride to the nitric acid dissolvent. ${ }^{6}$ This fluoride remains in the raffinate from the solvent extraction step.

Regardless of whether permanent tank storage, calcination to solids, or some other method is adopted for ultimate disposal of high-level radioactive wastes, there will be a need for some interim storage of these solutions. If they are to remain indefinitely in the storage tank they may be neutralized with alkali, but if they are ever to be completely rcmovea it is advantageous to keep them acid in order to minimize sludge formation and waste volume. Some method of removing the radiolytic heat will be necessary. Stainless steel is the obvious candidate of construc... tion for these tanks but its long-term resistance to corrosion by the solutions of interest must be established.

In general, the austenitic stainless steels are classed as having good resistance to nitric acid and to nitrate solutions of most metal ions. The presence of very small amounts of chromate causes intergranular attack, particularly in heat-affected areas surrounding weldments. $7-9$ Reports of intergranular attack due to high concentrations of $\mathrm{Fe}\left(\dot{t}_{3}\right)$ in nitric acid have been somewhat conflicting. ${ }^{, 8}$ The addition of as much as $800 \mathrm{ppm} \mathrm{Cl}^{-}$to such solutions had no effect on the rate of attack. ${ }^{3}$

\section{EYTERTITITAL}

Specimens of types 304I and 347 stainless cteels were exposed in the solution and vapor phases of simulated wastes from the solvent extraction (Purex Process) of residual uranium from the Darex (stainless steel $\mathrm{UO}_{2}$ fuel) and Darex-Thorex (stainless steel clad, $\mathrm{UO}_{2}-\mathrm{ThO}_{2}$ fuel) dissolution processes (Table 1 ). No simulation of fission products was attempted. Corrosion specimens of type 304L stainless steel were welded with type $308 \mathrm{~L}$ weld rod; those of type 347 were welded with type 347 weld rod. No heat treatment was given the specimens after welding. In some, but not all cases, weld beads were ground smooth before exposure. The effect of this grinding on the corrosion rate appeared to be primarily a decrease In the surface area of the specimen. In some experiments, stress specimons in the furm of bolted $U$-bends were exposed in the solution phase. Exposures were made at temperatures of 50,65 , and $80^{\circ} \mathrm{C}$ in both waste solutions and at $43^{\circ} \mathrm{C}$ and $35^{\circ} \mathrm{C}$ in Darex solutions containing $2 \mathrm{M}$ free acid. Test containers were glass for the Darex exposures; polyethylene or Kel-F was employed for containment of the Darex-Thorex waste solutions in order to prevent complications due to reaction of the fluoride with the container material. 
Table 1. Compositions of Darex-Purex and Darex-Thorex Waste Solutions

\begin{tabular}{|c|c|c|}
\hline \multirow{2}{*}{ Component } & \multicolumn{2}{|c|}{ Concentration (g-moles/liter) } \\
\hline & Darex-Purex & Darex-Thorex \\
\hline $\mathrm{H}^{+}$ & 2 to 5 & 1.13 \\
\hline $\begin{array}{l}\text { Stainless steel } \\
(304 \mathrm{~L})\end{array}$ & 1.82 & 1.82 \\
\hline $\mathrm{Al}(\mathrm{III})$ & -- & 0.28 \\
\hline $\mathrm{Cl}^{-}$ & $0.003(100 \mathrm{ppm})$ & $0.003(100 \mathrm{ppm})$ \\
\hline & -- & $0.036-0.04$ \\
\hline $\mathrm{NO}_{3}{ }^{-}$ & To balance & To balance \\
\hline
\end{tabular}

Specimens were removed weekly or bi-weekly for weighing and visual inspection. After exposures of several thousand hours, or upon the appearance of some peculiar phenomenon, specimens were examined metallographically to determine the nature of the attack and its extent in cases of localized attack. The simulated waste solutions were not renewed during testing since there would be no renewal during storage. After the corrosion behavior of the waste had been firmly established, additions were sometimes made to the solutions during confirmatory exposures to determine the effect of these additions on incremental corrosion rates.. Exceptions to this procedure were made in the case of inhibitors such as polyethylene, which were found to destroy the free acid. Periodic additions of acid were necessary in such cases in order to eliminate any effect of the decrease in acid concentration.

Electrode potentials were measured with a potentiometer in the conventional way by the use of a saturated calomel electrode. Brief polarization measurements were made by conventional methods. 10 The results were confirmed by an independent source. 11,12

\section{RESULTS}

Overall corrosion rates in Darex-Purex solutions (Table 1), based on welght losses, varled from less than $0.01 \mathrm{mil} / \mathrm{month}$ in the $2 \mathrm{M}$ acid solution at $35^{\circ} \mathrm{C}$ to $0.9 \mathrm{mil} / \mathrm{month}$ in the $5 \mathrm{M}$ acid solution at $80^{\circ} \mathrm{C}$. Corrosion rates on type 347 were invariably higher than on type 304I, and with both steels rates increased rapidly with increasing temperature (Tables 2-5, Figs. 1-5). Preliminary tests on Ni-o-nel were discontinued after $431 \mathrm{hr}$ of exposure because of intergranular attack.

In all tests at or above $50^{\circ} \mathrm{C}$ in the absence of inhibitors, grain boundary attack eventually became visible on all solution-phase specimens. Lowering the temperature of exposure or the concentration of free acid in the solution lowered the overall corrosion rate and extended the time before inception of the grain boundary attack (Figs. 2-6; Tables 2-5). 
Table 2. Corrosion Rates of Welded Specimens ${ }^{a}$ of Types 304L and 347 Stainless Steels in Simulated High-Acid Waste Solutions ${ }^{b}$ at $80^{\circ} \mathrm{C}$

\begin{tabular}{|c|c|c|c|c|}
\hline \multirow{2}{*}{$\begin{array}{l}\text { Test } \\
\text { Period } \\
(\mathrm{h} r)\end{array}$} & \multirow{2}{*}{$\begin{array}{c}\text { Type of } \\
\text { Stainless } \\
\text { Steel }\end{array}$} & \multicolumn{3}{|c|}{ Corrosion Rate (mil/month) } \\
\hline & & Vapor & Interface & Solution \\
\hline 168 & $\begin{array}{l}347 \\
304 \mathrm{~L}\end{array}$ & $\begin{array}{l}0.01 \\
0.02\end{array}$ & $\begin{array}{l}0.17 \\
0.18\end{array}$ & $\begin{array}{l}0.29 \\
0.29\end{array}$ \\
\hline 336 & $\begin{array}{l}347 \\
304 \mathrm{~L}\end{array}$ & $\begin{array}{l}0.01 \\
0.01\end{array}$ & $\begin{array}{l}0.18 \\
0.17\end{array}$ & $\begin{array}{l}0.32 \\
0.27\end{array}$ \\
\hline 570 & $\begin{array}{l}347 \\
304 \mathrm{I}\end{array}$ & $\begin{array}{l}0.01 \\
0.01\end{array}$ & $\begin{array}{l}0.22 \\
0.17\end{array}$ & $\begin{array}{l}0.43 \\
0.29\end{array}$ \\
\hline 738 & $\begin{array}{l}347 \\
304 \mathrm{I}\end{array}$ & $\begin{array}{l}0.01 \\
0.01\end{array}$ & $\begin{array}{l}0.25 \\
0.17\end{array}$ & $\begin{array}{l}0.52 \\
0.31\end{array}$ \\
\hline 906 & $\begin{array}{l}347 \\
304 \mathrm{~L}\end{array}$ & $\begin{array}{l}0.01 \\
0.01\end{array}$ & $\begin{array}{l}0.28 \\
0.18\end{array}$ & $\begin{array}{l}0.58 \\
0.34\end{array}$ \\
\hline 1074 & $\begin{array}{l}347 \\
304 \mathrm{~L}\end{array}$ & $\begin{array}{l}0.01 \\
0.01\end{array}$ & $\begin{array}{l}0.30 \\
0.19\end{array}$ & $\begin{array}{l}0.63 \\
0.36\end{array}$ \\
\hline 1574 & $\begin{array}{l}347 \\
304 \mathrm{~L}\end{array}$ & $\begin{array}{l}0.01 \\
0.01\end{array}$ & $\begin{array}{l}0.35 \\
0.21\end{array}$ & $\begin{array}{l}0.70 \\
0.43\end{array}$ \\
\hline 2074 & $\begin{array}{l}34.7 \\
304 \cdot \mathrm{L}\end{array}$ & $\begin{array}{l}0.01 \\
0.01\end{array}$ & $\begin{array}{l}0.1 .1 . \\
0.25\end{array}$ & $\begin{array}{l}0.78 \\
0.51\end{array}$ \\
\hline 3082 & $\begin{array}{l}347 \\
304 \mathrm{~L}\end{array}$ & $\begin{array}{l}0.01 \\
0.01\end{array}$ & $\begin{array}{l}0.45 \\
0.29\end{array}$ & $\begin{array}{l}0.81 \\
0.61\end{array}$ \\
\hline 4082 & $\begin{array}{l}347 \\
304 \mathrm{~L}\end{array}$ & $\begin{array}{l}0.01 \\
0.01\end{array}$ & $\begin{array}{l}0.51 \\
0.36\end{array}$ & $\begin{array}{l}0.90 \\
.0 .75\end{array}$ \\
\hline 5082 & $\begin{array}{l}347 \\
304 \mathrm{~L}\end{array}$ & $\begin{array}{l}0.01 \\
0.01\end{array}$ & $\begin{array}{l}0.52 \\
0.39\end{array}$ & $\begin{array}{l}0.88 \\
0.77\end{array}$ \\
\hline 6082 & $\begin{array}{l}31.7 \\
304 \mathrm{~L}\end{array}$ & $\begin{array}{l}0.01 \\
0.01\end{array}$ & $\begin{array}{l}0.53 \\
0.43\end{array}$ & $\begin{array}{l}0.89 \\
0.80\end{array}$ \\
\hline
\end{tabular}

all specimen surfaces polished with 120-grit paper.

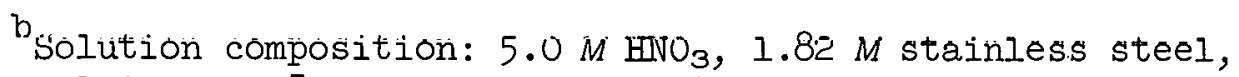
$100 \mathrm{ppm} \mathrm{Cl}{ }^{-}$. 
Table 3. Corrosion Rates of Welded Specimens of Types 304L and 347 Stainless Steels in Simulated High-Acid Darex-Purex Waste Solutions at $65^{\circ} \mathrm{C}$

(Average of results for two specimens)

\begin{tabular}{|c|c|c|c|c|c|}
\hline \multirow{2}{*}{$\begin{array}{l}\text { Test } \\
\text { Period } \\
(\mathrm{hr}) \\
\end{array}$} & \multirow{2}{*}{$\begin{array}{c}\text { Type of } \\
\text { Stainless } \\
\text { steel }\end{array}$} & \multicolumn{4}{|c|}{ Cumulative Corrosion Rate (mil/month) } \\
\hline & & Vapor & Interface & & Solution \\
\hline 168 & $\begin{array}{l}347 \\
304 \mathrm{~L}\end{array}$ & $\begin{array}{l}0.04 \\
\text { wt gain. }\end{array}$ & $\begin{array}{l}0.08 \\
0.02\end{array}$ & & $\begin{array}{l}0.10 \\
0.02\end{array}$ \\
\hline 336 & $\begin{array}{l}347 \\
304 \mathrm{~L}\end{array}$ & $\begin{array}{l}0.02 \\
0\end{array}$ & $\begin{array}{l}0.08 \\
0.02\end{array}$ & ' & $\begin{array}{l}0.11 \\
0.04\end{array}$ \\
\hline 504 & $\begin{array}{l}347 \\
304 \mathrm{I}\end{array}$ & $\begin{array}{l}0.02 \\
0.01\end{array}$ & $\begin{array}{l}0.08 \\
0.03\end{array}$ & & $\begin{array}{l}0.11 \\
0.05\end{array}$ \\
\hline 672 & $\begin{array}{l}347 \\
304 \mathrm{~L}\end{array}$ & $\begin{array}{l}0.02 \\
0.01\end{array}$ & $\begin{array}{l}0.08 \\
0.04\end{array}$ & & $\begin{array}{l}0.11 \\
0.07\end{array}$ \\
\hline 840 & 347 & 0.01 & 0.08 & & 0.11 \\
\hline 859 & $304 \mathrm{~L}$ & 0.01 & 0.04 & & 0.07 \\
\hline 1008 & 347 & 0.01 & 0.08 & & 0.12 \\
\hline 1176 & $\begin{array}{l}347 \\
304 \mathrm{~L}\end{array}$ & $\begin{array}{l}0.01 \\
0.01\end{array}$ & $\begin{array}{l}0.09 \\
0.05\end{array}$ & & $\begin{array}{l}0.12 \\
0.09\end{array}$ \\
\hline 1273 & $304 \mathrm{~L}$ & 0.01 & 0.05 & & 0.09 \\
\hline
\end{tabular}

Table 1. Corrosion Rates of Welded Specimiens of Type 304L Stainless Steel in Simulat.er High-Asid

Darex-Thorex Waste Soluliun at $50^{\circ} \mathrm{C}$

(Average of results for two specimens)

\begin{tabular}{|c|c|c|c|}
\hline Test Period & Cumulative & Corrosion Rate & $(\mathrm{mil} / \mathrm{month})$ \\
\hline$(h r)$ & Vapor & Interface & Solution \\
\hline 336 & 0.01 & 0.01 & 0.01 \\
\hline 504 & 0.01 & 0.01 & 0.01 \\
\hline 691 & 0.01 & 0.05 & 0.06 \\
\hline 859 & 0.01 & 0.06 & 0.07 \\
\hline 1027 & 0.01 & 0.05 & 0.06 \\
\hline 1195 & 0.01 & 0.04 & 0.01 \\
\hline 1363 & 0.01 & 0.04 & 0.04 \\
\hline 1521 & 0.01 & 0.05 & 0.05 \\
\hline
\end{tabular}


Table 5. Corroeion Rates cif Welded Types 347 and 304L Stainless

Steel in Simulated Low-Acid Darex-Purex Waste Solutions

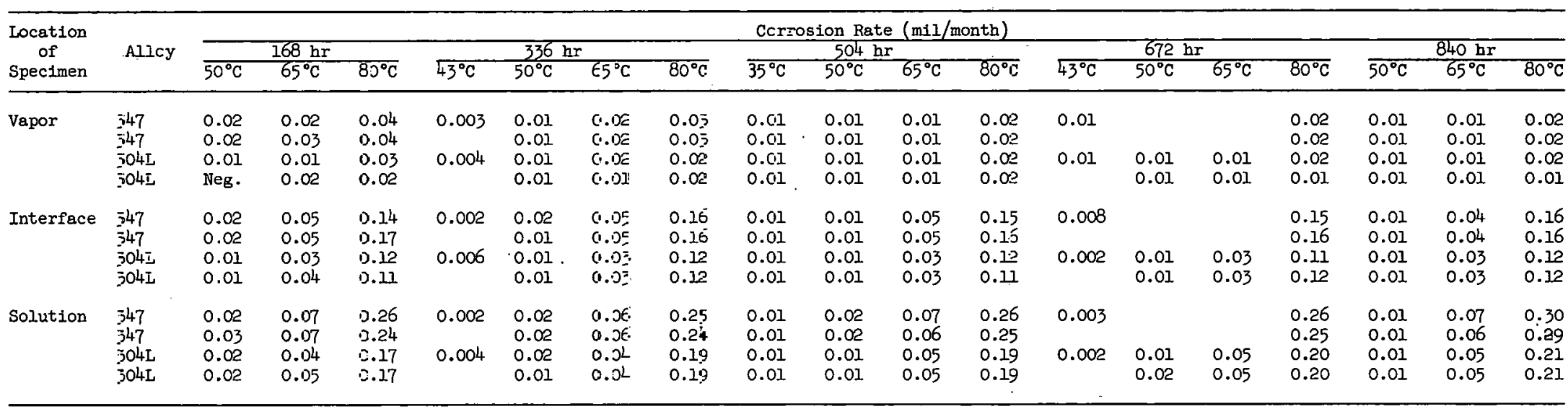

${ }^{a}$ Composition of waste: $2.0 \mathrm{M} \mathrm{MrO}_{3}, 1.82 \mathrm{M}$ stainless steel, $0.003 \mathrm{M} \mathrm{cl}^{-}$. 

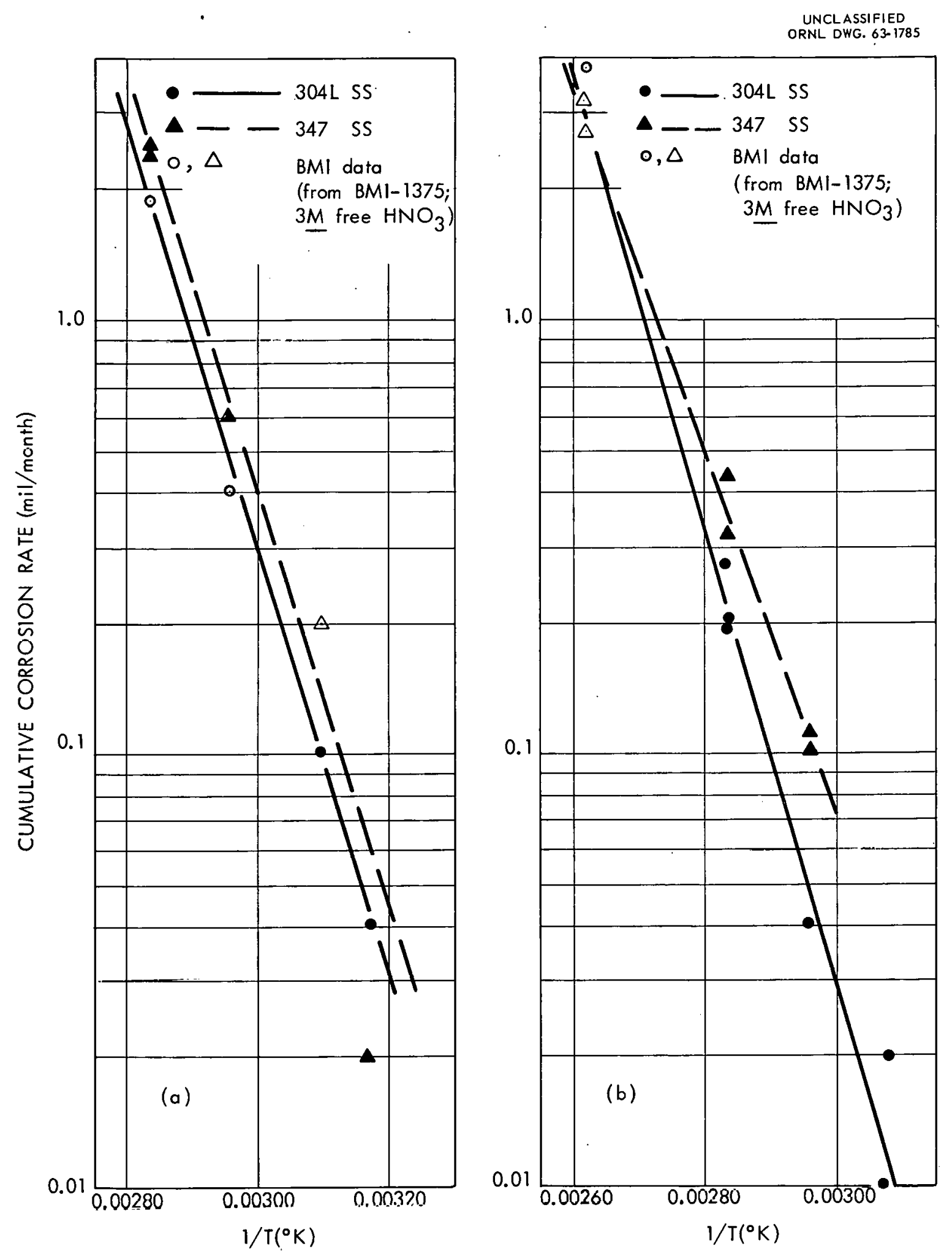

Fig. 1. Temperature Dependence of the Corrosion of Types 304L and 347 Stainless Steel in Simulated Darex-Purex Waste Solutions (a) 2 M in Free Acid, (b) $5 \underline{M}$ in Free Acid. 


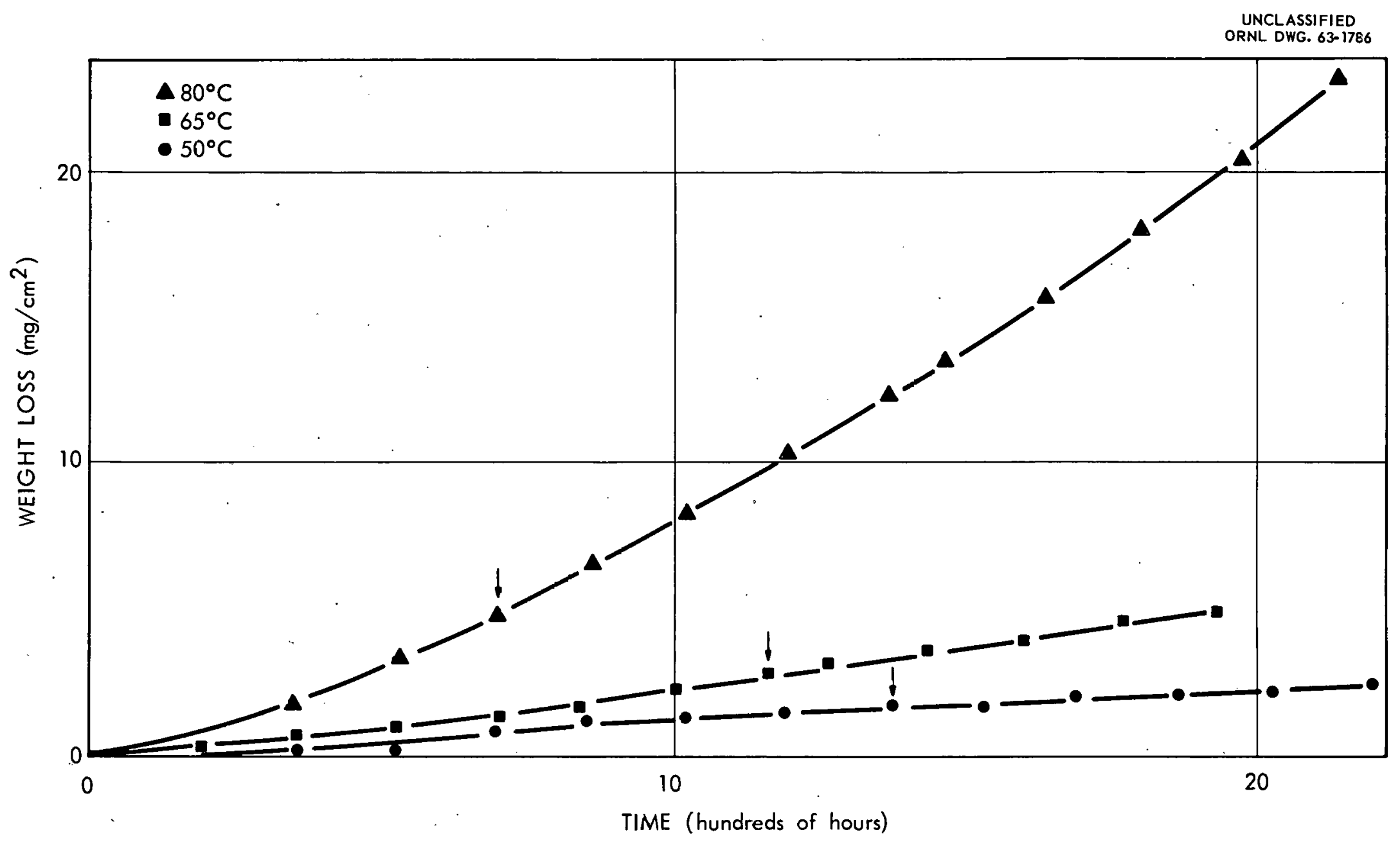

Fig. 2. Average Weight Loss at Three Temperatures of Two Welded, Type 304L Stainless Steel Specimens in Simulated Darex-Purex, Waste Solution. (Solution $5.0 \mathrm{M} \mathrm{HNO}_{3}, 1.82 \mathrm{M}$ stainless steel, $100 \mathrm{ppm} \mathrm{Cl}^{\circ}$.) Vertical arrows indicate times at which grain boundary attack was $\bar{f} i$ rst noted. 


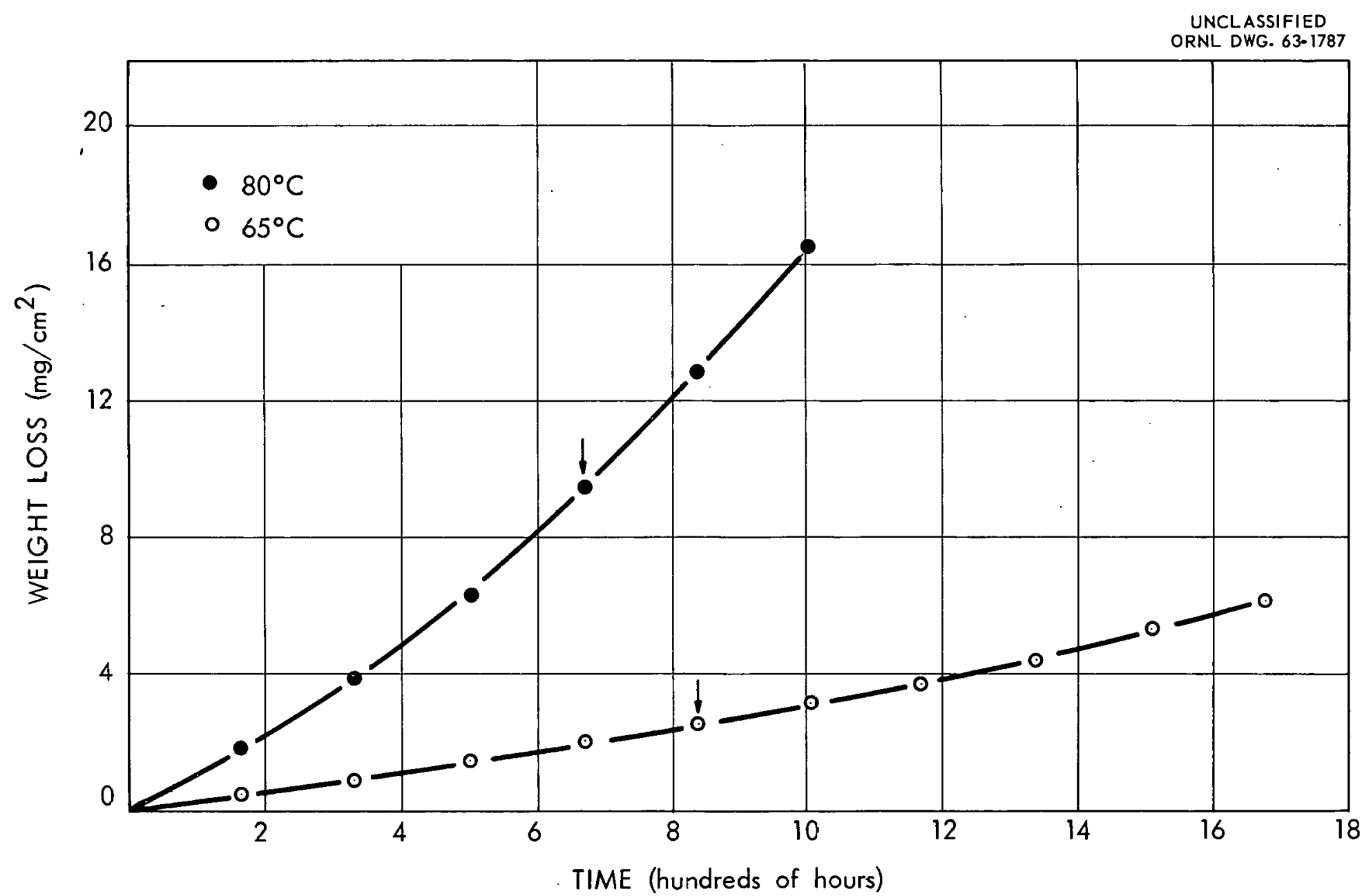

Fig. 3. Average Weight Loss at Two Temperatures for Two Welded, Type 347 Stainless Steel Specimens in Simulated Darex-Purex, Waste Solution. (Solution $5.0 \mathrm{M} \mathrm{HNO}_{3}, 1.82 \mathrm{M}$ stainless steel, $100 \mathrm{ppm} \mathrm{Cl}^{-}$.) Vertical arrows indicate times at which grain boundary attack was first roted. 


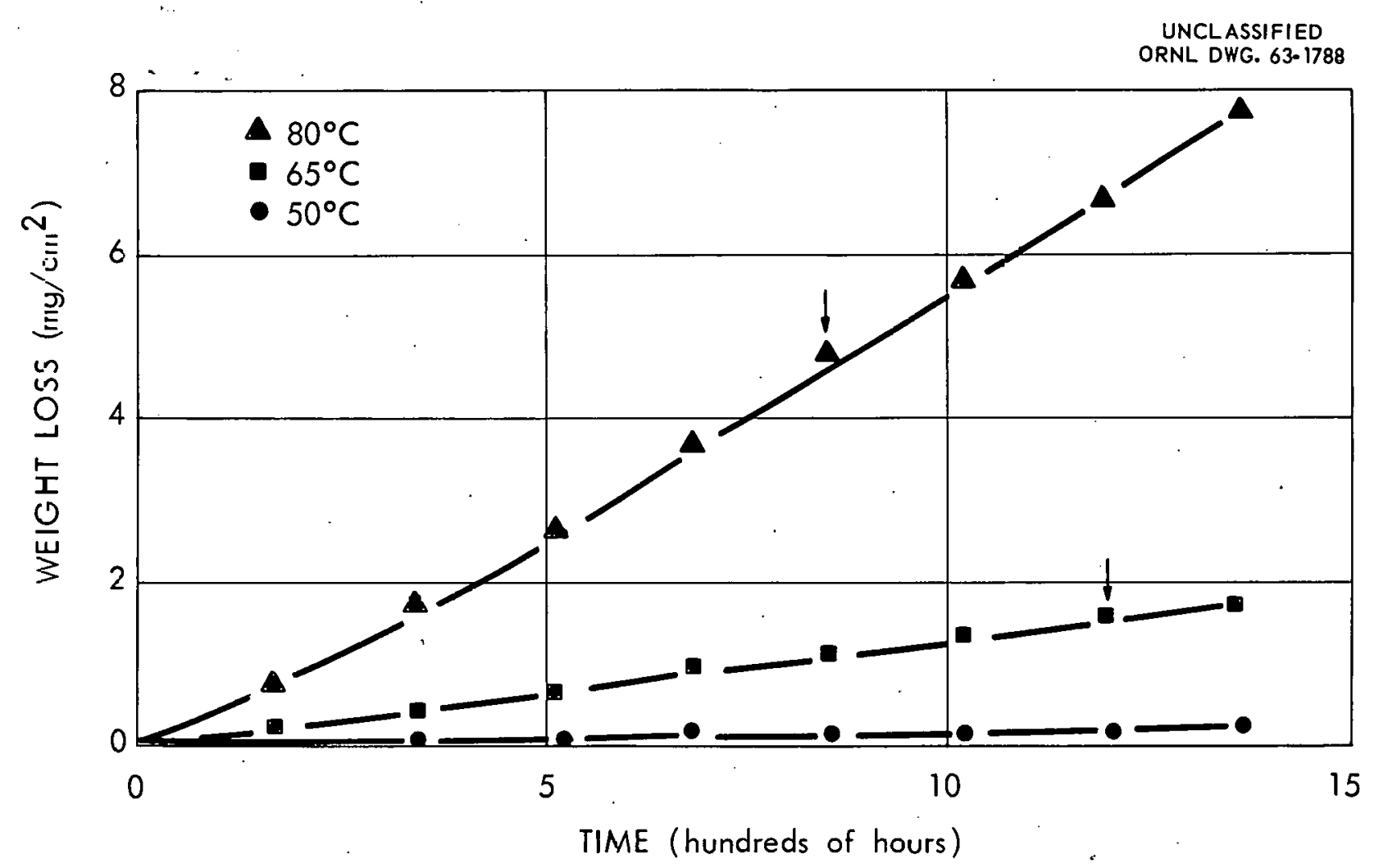

Fig. 4. Average Weight Loss at Tiree Temperatures of Two Welded, Type 304L Stainless Steel Specimens in Simulated Darex-Purex Waste Solution. (Solution $2.0 \mathrm{M} \mathrm{HINO}_{3}$, $1.82 \mathrm{M}$ stainless steel; $100 \mathrm{ppm} \mathrm{Cl}{ }^{-}$.) Vertical arrows represent times at which grain boundary attack was first noted. 


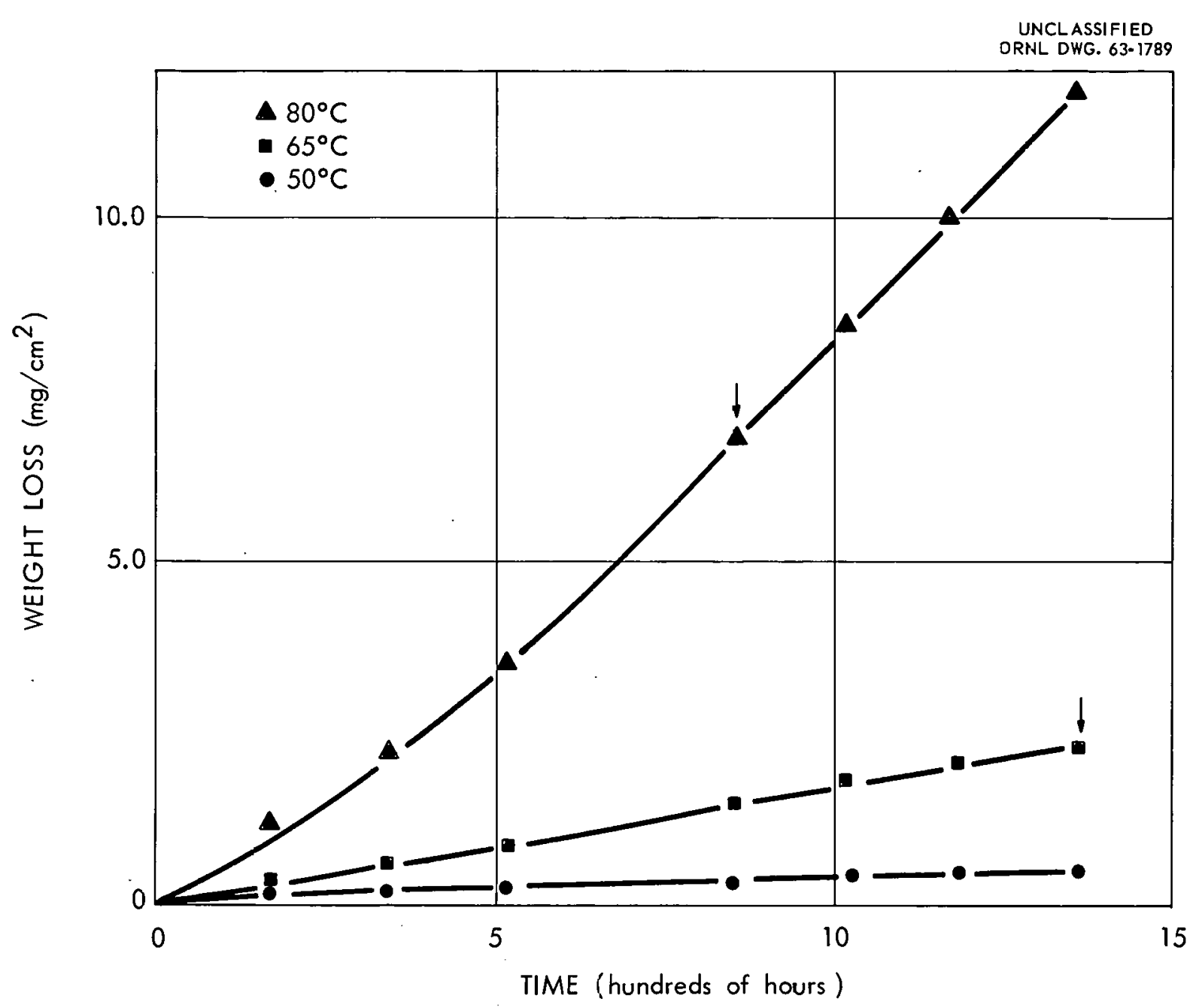

Fig. 5. Average Weight Loss at Three Temperatures of Two Welded, Type 347 Stainless Steel Specimens in Simulatec Derex-Purex Waste Solution. Compoition of solutinn: $2.0 \mathrm{M} \mathrm{HNO}_{3}, 1.82 \mathrm{M}$ stainless steel, $100 \mathrm{ppm} \mathrm{CI}{ }^{-}$. Vertical arrows indicate times at which grain boundary attack wass first noted. 


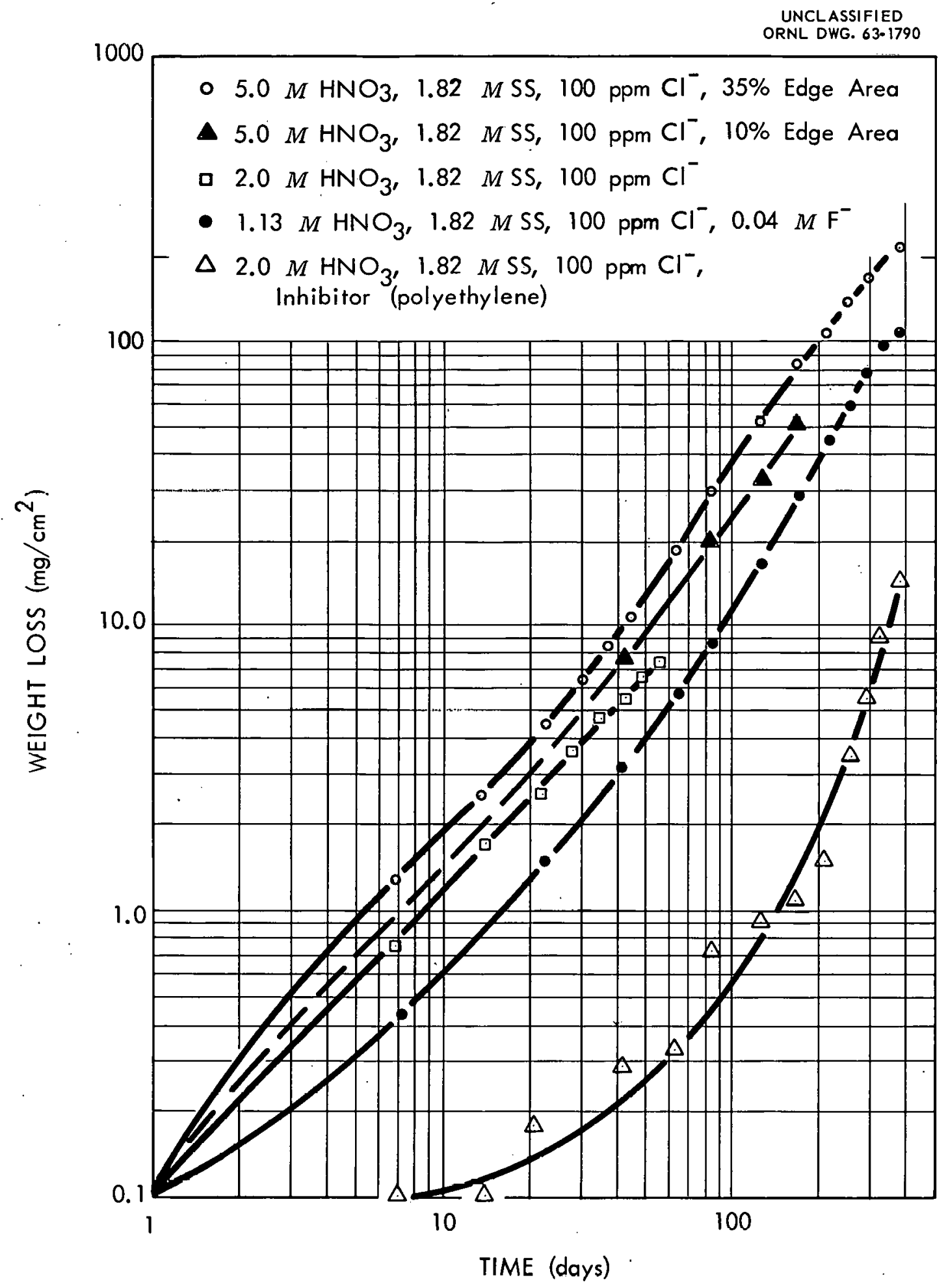

Fig. 6. Effect of Acid Concentration, Edge Area, and Inhibitor on the Corrosion of Type 304L Stainless Steel During Long-Term Exposure at $80^{\circ} \mathrm{C}$. 
Even at $80^{\circ} \mathrm{C}$ and $7000 \mathrm{hr}$ of exposure, however, this corrosion failed to develop into true intergranular attack.

In all cases the highest corrosion rates were experienced by specimens exposed in the solution phase. Specimens that presented no edge surface to the solution corroded at slightly lower rates than ordinary specimens (Fig. 6). Stressed specimens showed no increase in corrosion compared with unstressed specimens (Fig. 7).

The initial exposures in Darex-Thorex solutions (Table 1) resulted in lower rates than those observed in the Darex-Purex solutions that contained no fluoride. Further investigation revealed that this inhibition was due to some unidenlified material leached I'rom the polyethylene containers (Table 6). When the Darex-Thorex exposures were repeated with fluorocarbon plastic containers the results were consistent with the acid effect observed in Darex-Purex waste solutions (Fig. 6). The presence of the small amount of fluoride did not, therefore, appear to have any significant effect on the corrosion process.

The most aggressive attack observed below reflux temperatures consisted of end-grain attack, which at $80^{\circ} \mathrm{C}$ was sometimes catastrophic (Fig. 8).

The addition of polyethylene chips to the waste solution reduced the corrosion rate in the low acid $(2 M)$ solution from 0.36 to $0.02 \mathrm{mil} / \mathrm{month}$ for exposures of $6036 \mathrm{hr}$ (Table 6, Fig. 6). During this exposure it was noted that the polyethylene reduced the concentration of the free nitric acid considerably; enough extra nitric acid was added periodically to have made the starting solution $6.3 \mathrm{M}$ in free acid, whereas, in the absence of polyethylene, the additional acid required to replace evaporation and other losses would have increased the initial acid concentration to only $2.3 \mathrm{M}$ had it all been present initially. The inhibitor appeared to be eventually consumed. The same inhibiting effect was obtained by exposing the specimens in a solution in which polyethylene chips had been refluxed for $50 \mathrm{hr}$. This phenomenon has not been adequately explained nor has the inhibitor been identified. The grain-boundary attack characteristic of these waste solutions appeared on the specimens long before the inhibitor was consumed.

The occurrence of the grain-boundary attack with the corresponding increase in overall corrosion rate, plus the fact that some leachant from polyethylene acted as an inhibitor, made it desirable to determine the agent responsible for the attack and to investigate the possibility of effectively inhibiting it. A number of diagnostic exposures were therefore made in which the solution constituents were varied. All these exposures were made at $80^{\circ} \mathrm{C}$ in order to accererate the corrosion rate as much as possible without the complications which would be introduced by exposure in a boiling solution. Type 304L specimens were used in these tests. The results of some of the more conclusive tests are presented graphically in Figs. 9-12, in which the average incremental weight losses of duplicate specimens are plotted vs the number of exposure periods. 


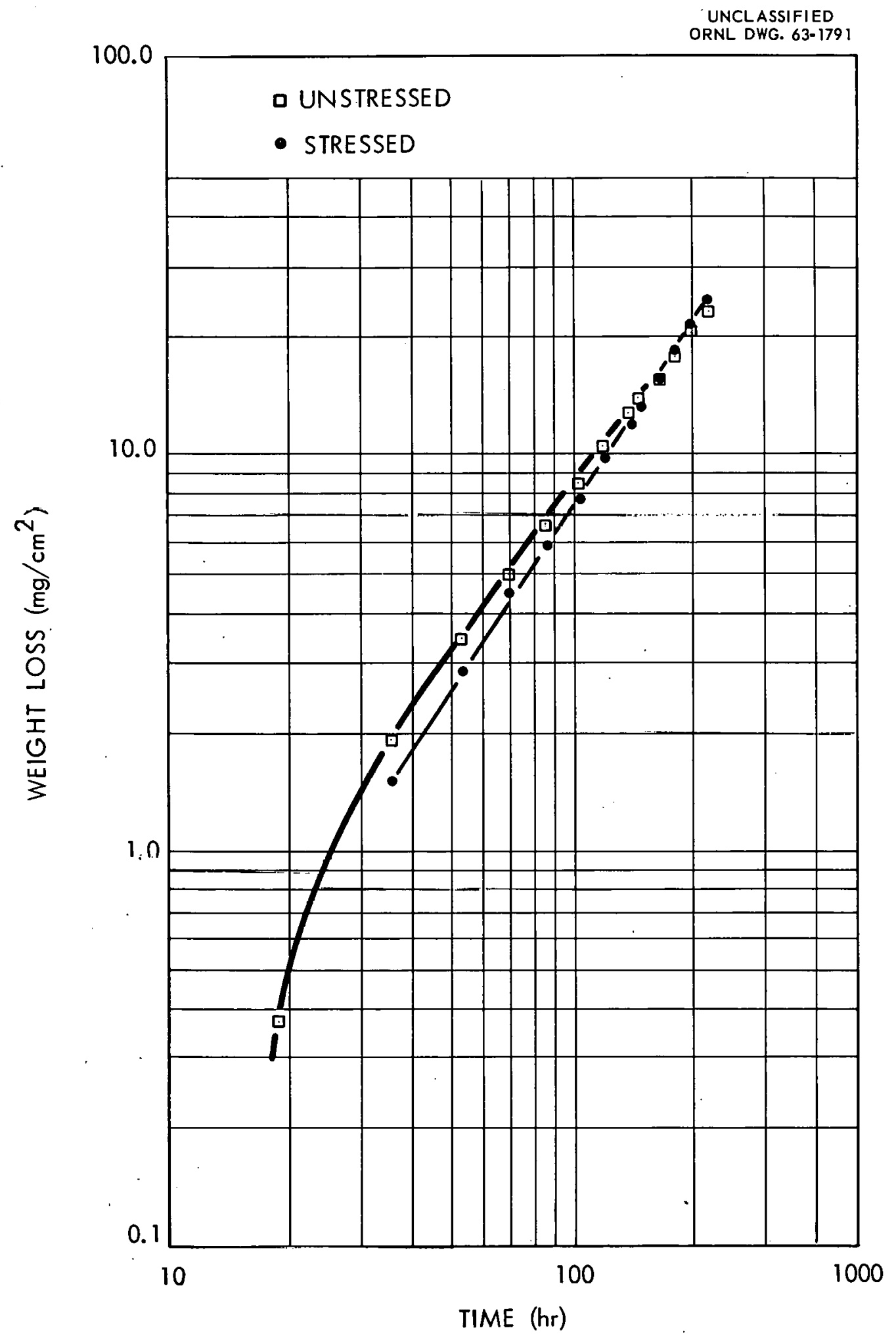

Fig. 7. Corrosion Rates of Stressed Type 304L vs Unstressed Type 304L.

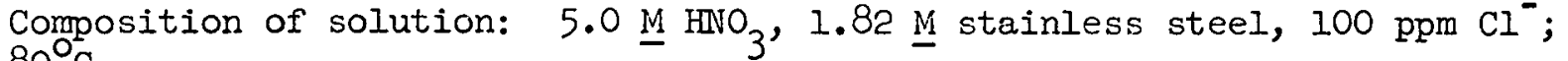
$80^{\circ} \mathrm{C}$. 
Table 6. Corrosion Rates of Types 304L Stainless Steel in Simulated Low-Acid Darex-Purex Solution at $80^{\circ} \mathrm{C}$ with and without added Polyethylene Chips

$$
\text { (Average of two specimens) }
$$

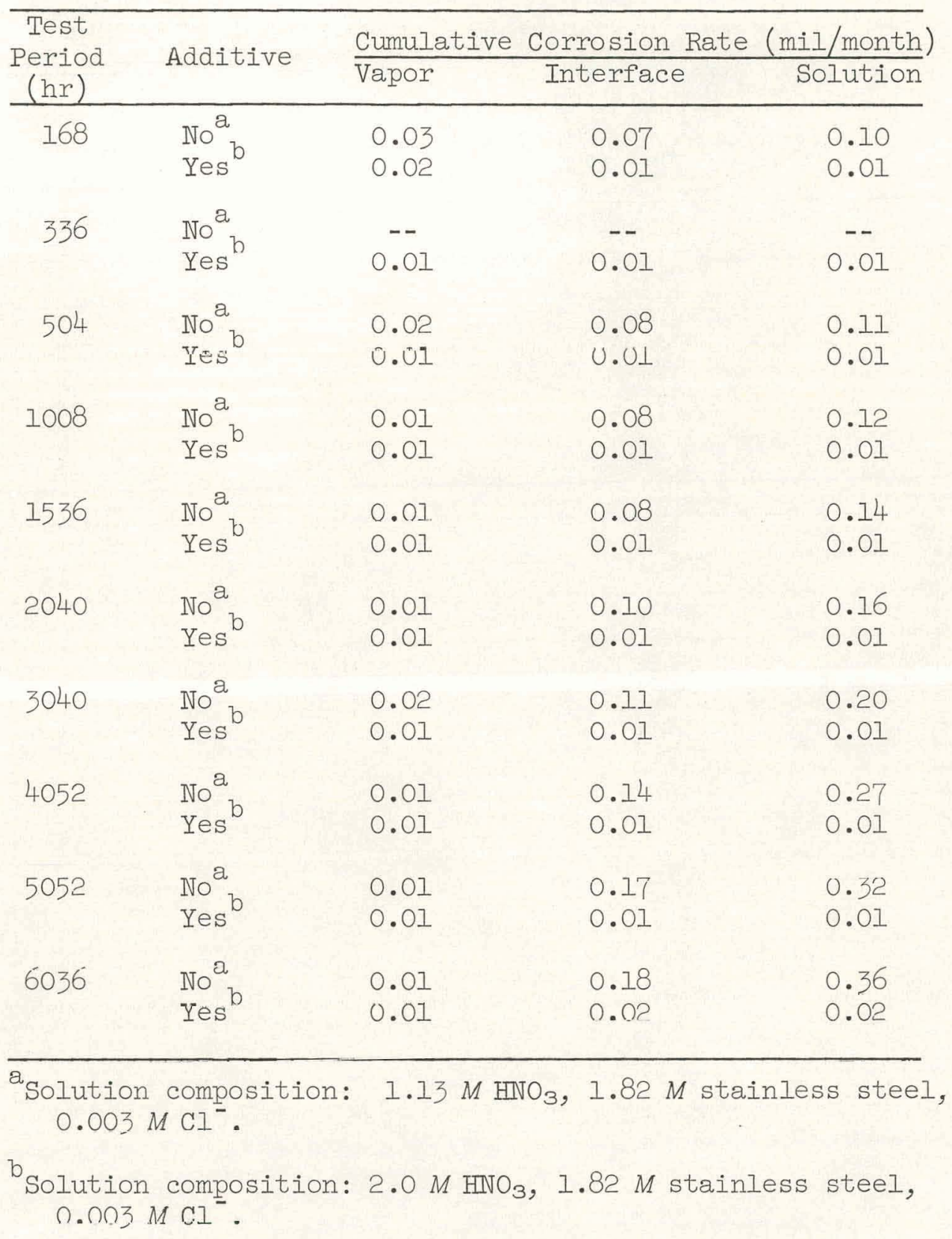




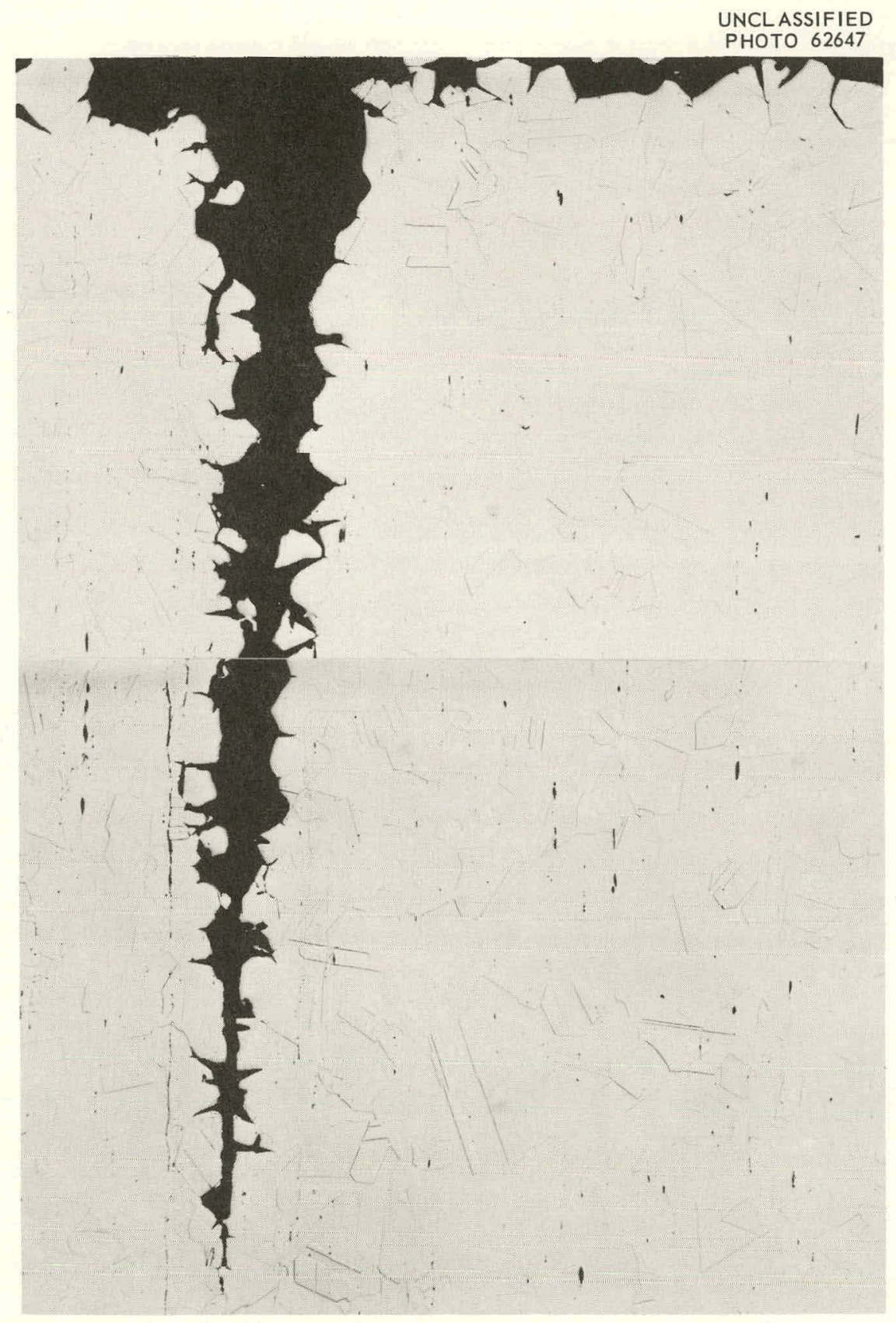

Fig. 8. Severe End-Grain Attack on Typc 304I Stainless Steel in Simulated Darex-Purex Waste Solution at $80^{\circ} \mathrm{C}$. $100 \mathrm{X}$ 
Comparison of the corrosion in a solution prepared by dissolving stainless steel with that in one prepared directly from reagents indicated that the initial corrosion was higher in the first case but that the two reached approximately equivalent rates after about $4000 \mathrm{hr}$ ( 24 weeks) of exposure (Fig. 9). Decreasing the concentration of Fe(III) in the solution from 1.27 to $0.13 \mathrm{M}$ reduced the weight loss from about 5 to about $0.65 \mathrm{mg}$ for the first 10 weeks (about $1680 \mathrm{hr}$ ) of exposure; corresponding cumulative corrosion rates over this exposure time were 0.4 and 0.07 $\mathrm{mil} / \mathrm{month}$, respectively. Lowering the concentration of $\mathrm{Fe}$ (III) to $4.2 \mathrm{x}$ $10^{-4} \mathrm{M}$ lowered the initial weight loss to $0.33 \mathrm{mg}$ and the corresponding cumulative rates to about $0.07 \mathrm{mil} /$ month. These are almost identical with the results obtained in solutions containing no added $\mathrm{Fe}$ (T.TI); at these low concentrations the iron present as contaminant was probably as great as that added. Since 0.1 to $0.2 \mathrm{mg}$ may be considered the limit of precision in weighing specimens of the gross weight used ( 9 to $12 \mathrm{~g}$ ), variations in weight below about $0.5 \mathrm{mg}$ are significant only if enough midsurements are made to ensure statistical validity.

Increasing the concentration of $\mathrm{Fe}$ (III) from 0.13 to $1.0 \mathrm{M}$ after 10 weeks exposure resulted in a sharp increase in the rate of corrosion until it approximated that of the simulated synthetic waste solution. Omission of the $\mathrm{Fe}$ (III) from the simulated waste solution lowered the average weight loss of the corrosion specimens to $0.25 \mathrm{mg} / \mathrm{cm}^{2} .2$ weeks or less for exposures of 10 weeks or longer (Figs. 9, 10). The substitution of $3 \mathrm{M}$ free acid, $1.27 \mathrm{M} \mathrm{Cr}$ (III) nitrate or $1.27 \mathrm{M} \mathrm{Al}$ (III) nitrate for the 1.27 $M F e(I I I)$ did not noticeably increase the corrosion above that in the solution with no Fe(III). Omission of $\mathrm{Cr}$ (III) from the simulated waste usually resulted in decreased corrosion (Fig. Il). Addition of $\mathrm{Cr}$ (IV) in concentrations equal to or greater than $1 \times 10^{-3} \mathrm{M}$ invariably increased the corrosion rate. In the absence of $\mathrm{Fe}$ (III) this increase was usually temporary (Fig. 10). In some instances Cr(III) appeared to stabilize the increased rate in a manner similar to $F e$ (III) while in others it appeared to exert no euch cfitect. Test solulions containing $\mathrm{Cr}$ (VI) which were heated to $80^{\circ} \mathrm{C}$ fur 24 hours prior to insertion of the specimens failed to produce the accelerated attack characteristic of $\operatorname{cr}(\mathrm{VI})$. The latter is, therefore, concluded to be unstable in these solutions. Analytical tests for $\mathrm{Cr}(\mathrm{VI})$ were inconclusive.

A number of organic and inorganic compounds were tested for possible effectiveness as inhibitors in the simulated waste solution. Of the inorganic materials tested, $\mathrm{NaH}_{2} \mathrm{PO}_{4}$ and $\mathrm{Zn}$ (II) either had no ettect or accelerated the corrosion slightly, while $F e(I I)$ sulfate was a mild inhibitor (Table 7). All the organic materials inhibited to some degree, but all were eventually consumed in the process, and $\mathrm{NO}_{2}$ was slowly evolved during exposures in solutions containing inhibitors. Intermittent bubbling of $\mathrm{NO}_{2}$ through a waste solution produced some inhibition. The corrosion rate increased sharply when the $\mathrm{NO}_{2}$ was stopped, and increased even more when $\mathrm{O}_{2}$ or $\mathrm{N}_{2}$ was substituted for $\mathrm{NO}_{2}$ (Fig. 12). Of the 


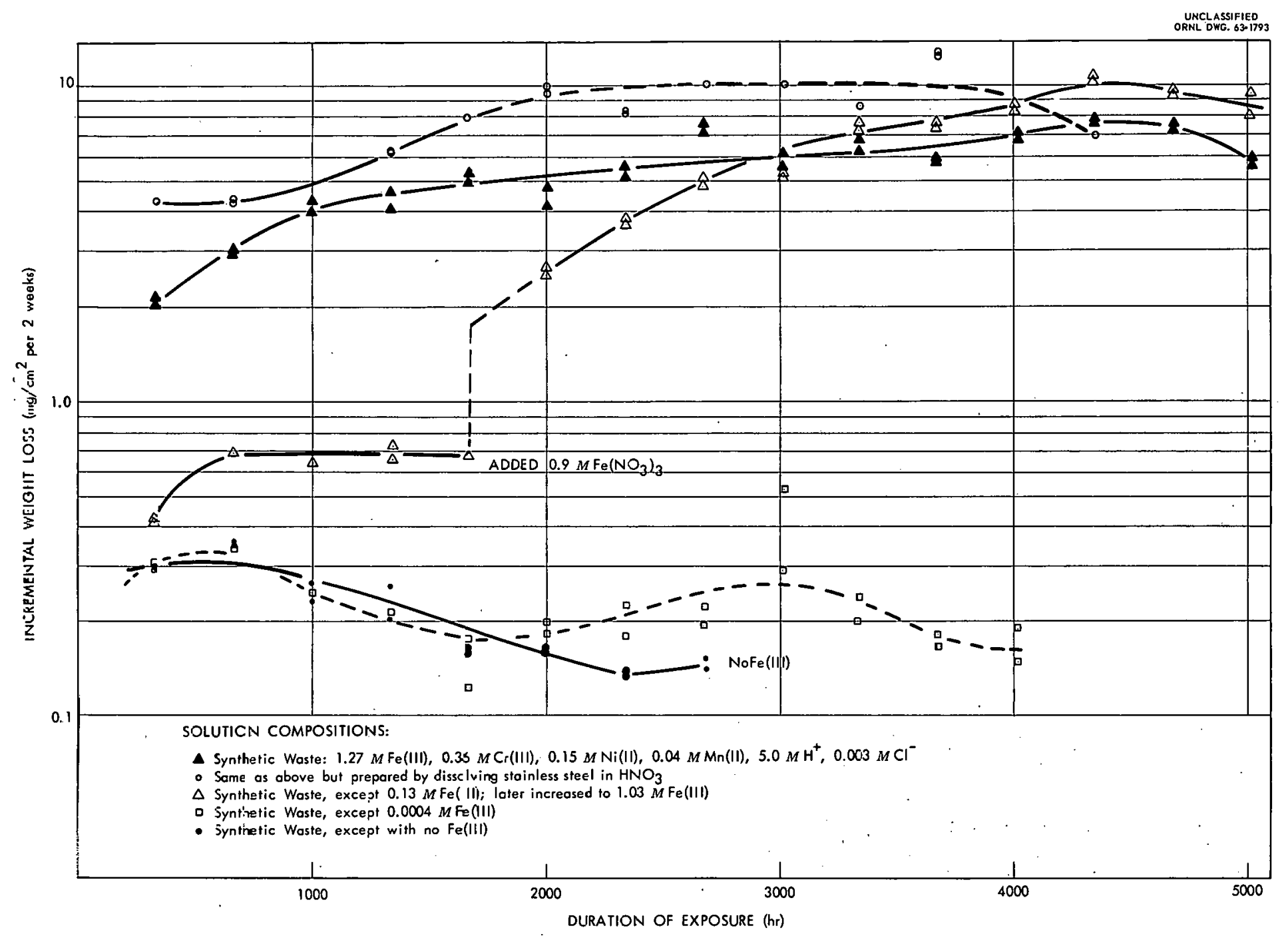

Fig. 9. The Effect of $\mathrm{Fe}\left(\mathrm{NO}_{3}\right)_{3}$ Concentration $8^{n}$ the Corrosion of Type $304 \mathrm{~L}$ Stainless Steel in Synthetic Darex-Purex Waste Solution at $80^{\circ} \mathrm{C}$. 


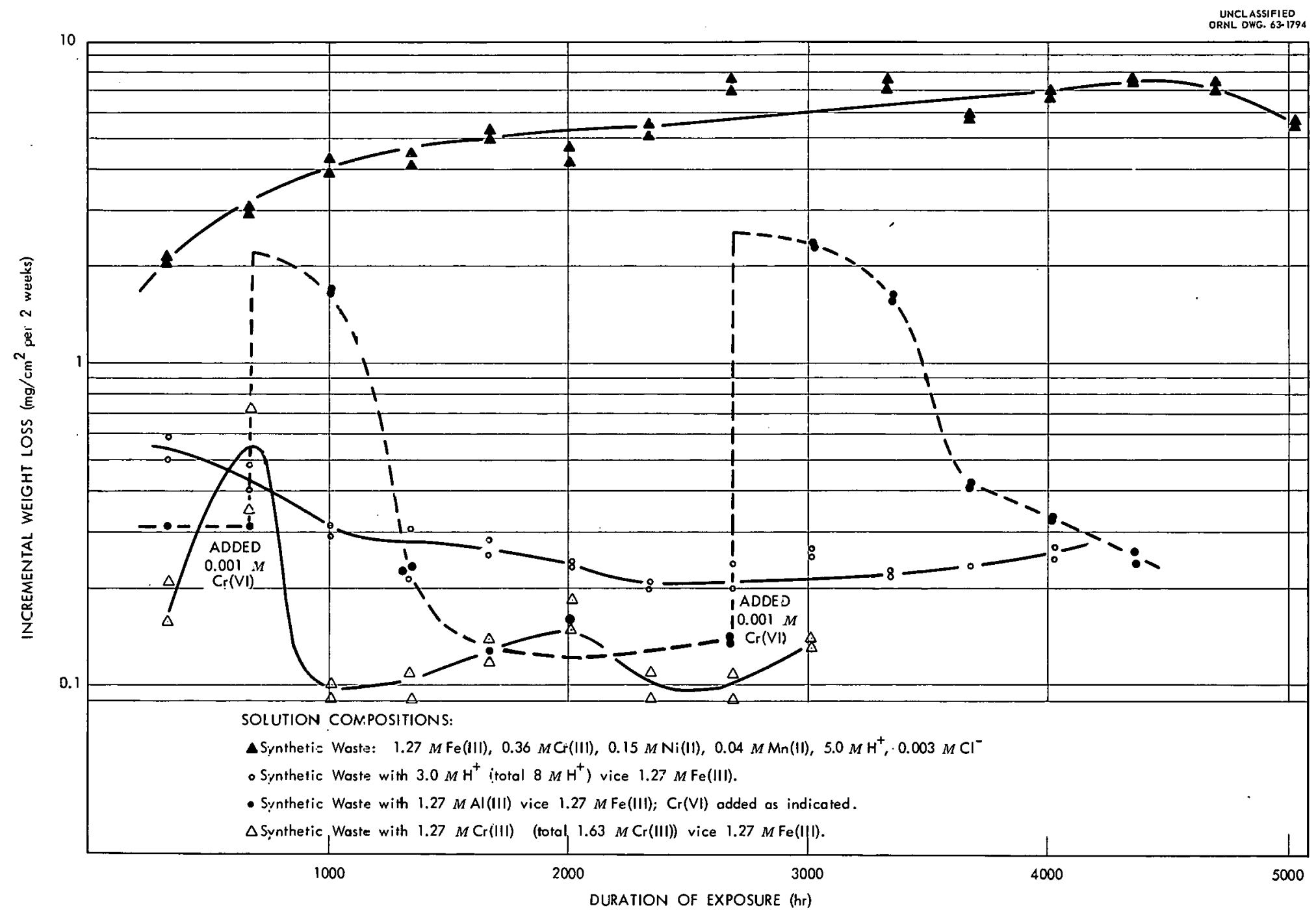

Fig. 10. The Effect of Substituting other Cations for Fe(III) or the Corrosion of Type 304L Stainless Steel in Synthetic Darex-Purex Waste Solution at $80^{\circ} \mathrm{C}$. 


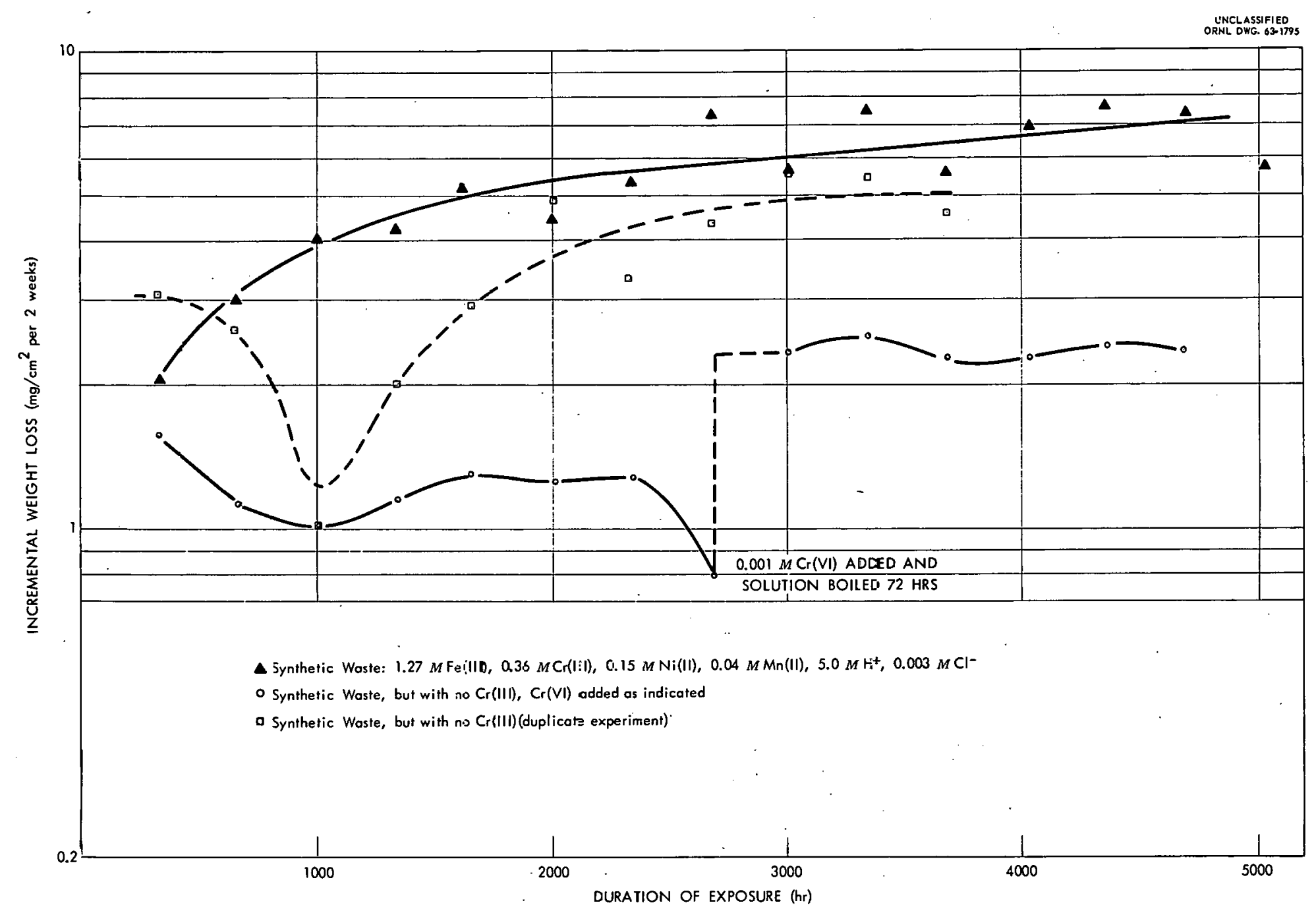

Fig. 11. The Effect of $\mathrm{Cr}\left(\mathrm{NO}_{3}\right)$ 三 on the Corrosion of Type 304L Stainless Steel in Synthet-c Darex-Purex Waste Solution at $80^{\circ} \mathrm{C}$. Points represent average of two determinations. 


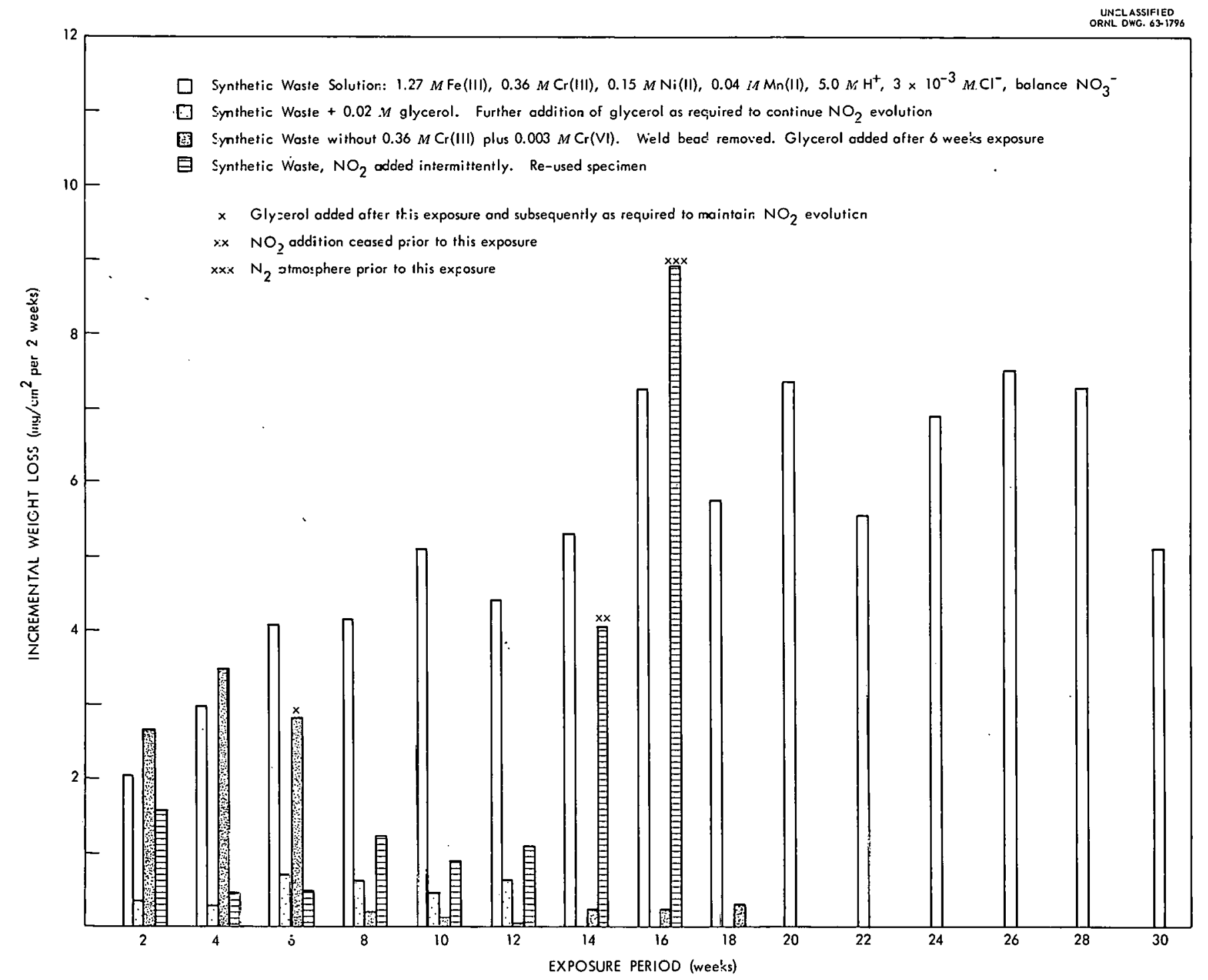

Fig. 12. The Effect of Glycerol and $\mathrm{NO}_{2}$ on the Corrosion of Type 304L Stainless Steel in Darex-Purex Waste at $80^{\circ} \mathrm{C}$. 
Table 7. The Effect cf Compounds Added to Darex-Purex Solution at $80^{\circ} \mathrm{C}$ on the Corrosion of Stainless Steel

\begin{tabular}{|c|c|c|c|c|c|c|c|c|}
\hline \multirow{3}{*}{ Compound } & \multirow{2}{*}{\multicolumn{4}{|c|}{$\begin{array}{l}\text { Incremental Weight Loss } \\
\left(\mathrm{mg} / \mathrm{cm}^{2} \text { per } 2 \text { weeks }(336 \mathrm{hr})\right. \\
\text { Type } 304 \mathrm{~L}\end{array}$}} & \multicolumn{4}{|c|}{$\begin{array}{l}\text { Cumulative Corrosion Rate } \\
\text { (mil/month) }\end{array}$} \\
\hline & & & & & \multicolumn{2}{|c|}{ Type $304 \mathrm{~L}$} & \multicolumn{2}{|c|}{ Type 347} \\
\hline & $1 \mathrm{wk}$ & 2 wks & I wk & 2 wks & I Wk & 2 wks & I wk & 2 wks \\
\hline None & 2.12 & 2.29 & 3.95 & $\dot{5} .56$ & 0.23 & 0.24 & 0.43 & 0.51 \\
\hline $\mathrm{Na}_{2} \mathrm{H}\left(\mathrm{PO}_{4}\right)_{3}, 0.1 \mathrm{M}$ & 2.72 & 2.69 & -- & -- & $0 . \geq 0$ & 0.29 & -- & -- \\
\hline Tributyl phosphate, $0.02 \mathrm{M}$ & 1.20 & 1.45 & 3.45 & 4.52 & 0.13 & 0.16 & 0.37 & 0.42 \\
\hline Dextrose, $0.02 \mathrm{M}$ & 2.56 & $2 \cdot 52$ & -- & -- & 0.28 & 0.28 & -- & -- \\
\hline Ethanolamine, $0.7 \mathrm{M}$ & 0.60 & 0.49 & - & -- & 0.06 & 0.06 & -- & -- \\
\hline $\mathrm{Zn}\left(\mathrm{NO}_{3}\right)_{2}, 0.05 \mathrm{M}$ & 2.66 & 2.87 & $\cdots$ & $\ldots$ & 0.29 & 0.30 & -- & -- \\
\hline o-Cresol, $0.02 \mathrm{M}$ & 0.70 & $2 \cdot .8$ & - & - & 0.08 & 0.15 & - & -- \\
\hline $\mathrm{FeSO}_{4}, 0.05 \mathrm{M}$ & 1.84 & $\cdots$ & -- & -- & 0.20 & -- & -- & -- \\
\hline Glycercl, $0.02 \mathrm{M}$ & 0.36 & $0 . \overline{3} 1$ & 0.30 & 0.22 & 0.04 & 0.04 & 0.03 & 0.03 \\
\hline
\end{tabular}


inhibitors studied, glycerol appeared to be generally the most effective. The periodic addition of glycerol so as to keep $\mathrm{NO}_{2}$ visible above the solution resulted in weight losses of 0.3 to $0.6 \mathrm{mg}$ per $\mathrm{cm}^{2}$ per 2 weeks, even on specimens that had previously suffered weight losses 10 to 20 times this size just prior to the addition of the inhibitor (Fig. 12).

A series of rather approximate emf measurements was made on platinum and on stainless steel electrodes in $5 \mathrm{M} \mathrm{HNO}_{3}$ at $80^{\circ} \mathrm{C}$, and in simulated waste solution at $80^{\circ} \mathrm{C}$ both before and after the addition of various concentrations of $\mathrm{Cr}(\mathrm{VI})$ and hydrogen peroxide. The results indicated the corrosion potential of stainless steel in the waste solution at $80^{\circ} \mathrm{C}$ to be about $930 \mathrm{mv}$ positive to the saturated calomel electrode. Addition of $5 \times 10^{-2} \mathrm{M} \mathrm{Cr}(\mathrm{VI})$ raised lhis potential to about +960 Irrv vs the SCE. After the addition of $\mathrm{Cr}(\mathrm{VI})$, considerable time, cooling, or the addition of a reducing agent, was necessary to cause the stainless steel potential to revert to its normal corrosion value. The addition of glycerol lowered the potential to about $+885 \mathrm{mv}$ ve the SCE. A plot of putenlial vs the molarity of $\mathrm{Cr}$ (VI) for the platinum electrode in $5 \mathrm{M} \mathrm{HNO}_{3}$ at $80^{\circ} \mathrm{C}$ had a slope approximating that for a three electron valence change (i.e., 0.027 vs 0.023 theoretical) for $\mathrm{Cr}(\mathrm{VI})+3 e \stackrel{\leftarrow}{\rightarrow} \mathrm{Cr}$ (III), but the presence of a stainless steel electrode in the same solution caused the potentials of the platinum to shift to much lower values, a plot of which did not closely correspond to any single, simple valence change (Fig. 13). This mixed potential behavior is doubtless due to the presence of a mixture of $\mathrm{Fe}$ (II), $\mathrm{Fe}$ (III), and oxides of nitrogen in the solution. The potential of platinum in the simulated waste solution containing $\mathrm{Cr}$ (VI) was much lower than in $5 \mathrm{M} \mathrm{HNO}_{3}$ in the presence of $\mathrm{Cr}(\mathrm{VI})$ and a siainless steel electrode, but increased slowly with time. In the absence of added chromate and of undissolved stainless steel, a platinum electrode at $80^{\circ} \mathrm{C}$ assumed a potential of about $+990 \mathrm{mv}$ vs the SCE in $5 \mathrm{M}$ acid and in the simulated waste solution. By comparison, a platinum electrode in a waste solution containing about $0.05 \mathrm{MCr}(\mathrm{VI})$ at $80^{\circ} \mathrm{C}$ and in the presence of a stainless steel electrode assumed a potential of between +1040 and $+1085 \mathrm{mv}$ vs the SCE; boiling the solution followed by addition of excess $\mathrm{H}_{2} \mathrm{O}_{2}$, cooling to $30^{\circ} \mathrm{C}$ and reheating to $80^{\circ} \mathrm{C}$ resulted in returm of the platinum potential to +990 to $+1000 \mathrm{mv}$ vs the SCE. It does not, therefore, appear likely that any appreciable equilibrium concentration of $\mathrm{Cr}(\mathrm{VI})$ can exist in an actual waste solution.

Brief polarization studies of stainless steel in the waste solution at $30^{\circ} \mathrm{C}$ indicated an open-circuit potential of abuut $+900 \mathrm{mv}$ vs the $\mathrm{SCE}$. Aggressive corrosion was shown to begin at potentials more positive than $1000 \mathrm{mv}$, but between this polential and about $+400 \mathrm{mv}$ there was relatively little change in the corrosion current (Fig. 14). Assuming the polarization curve to have the same general shape at $80^{\circ} \mathrm{C}$ as at $25^{\circ} \mathrm{C}$, it may be posisiule lo prevent the onset of very aggressive corrosion by polarizing the tank to about 700 to $800 \mathrm{mv}$ positive to the SCE. There appears to be no real dallyt uf such attack occurring when dealing with actual radioactive waste solutions because of the expected slow generation of oxides of nitrogen by radiolysis of dissolved nitrate. Results confirming the nature and shape of the polarization curve were obtained from two independent sources.11,12 


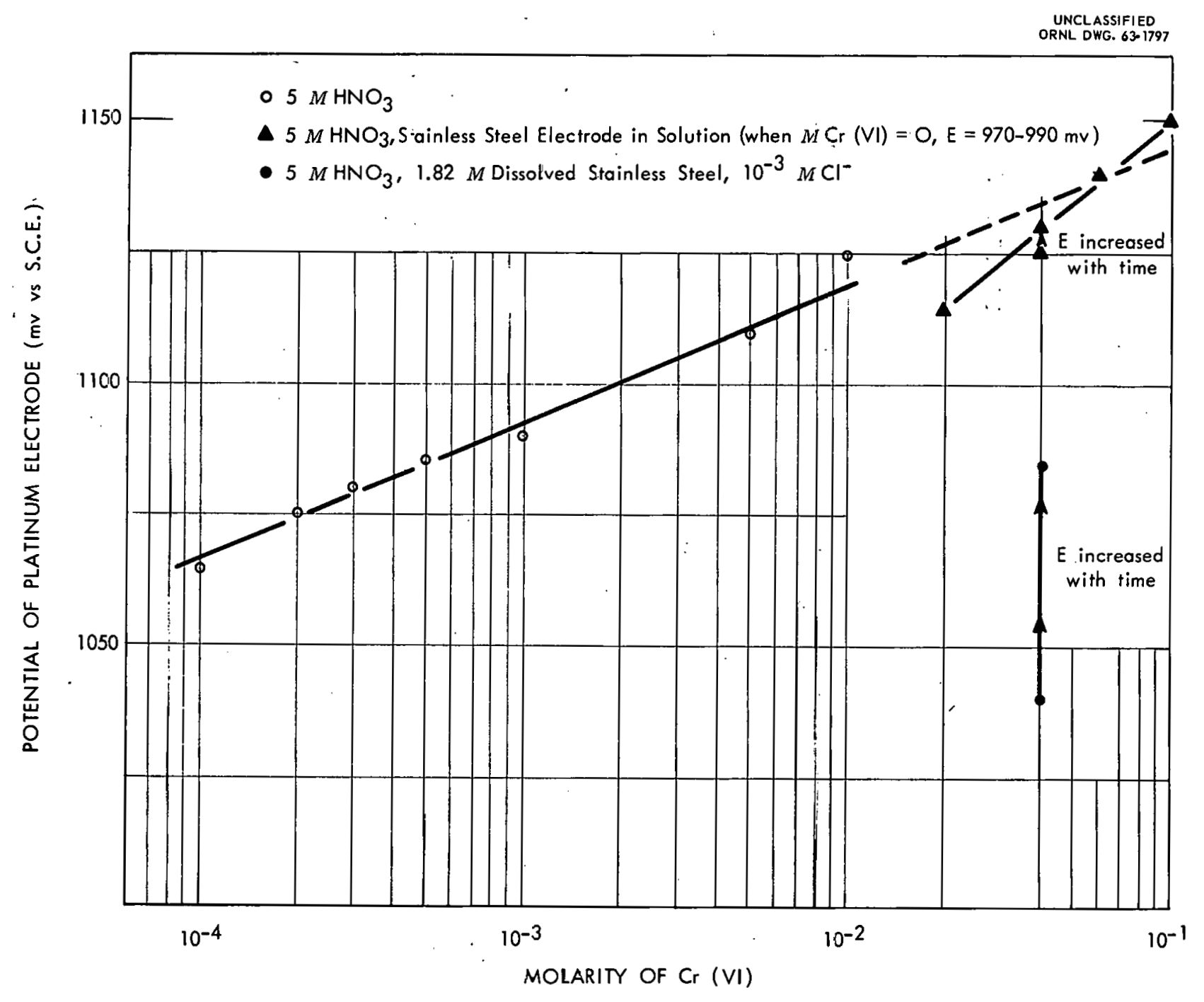

Fig. 13. The Potential of Smooth Platinum Electrodes as a Function of $\mathrm{Cr}$ (VI) Concentration in $5 \mathrm{MNNO}_{3}$ Solutions at $80^{\circ} \mathrm{C}$. 


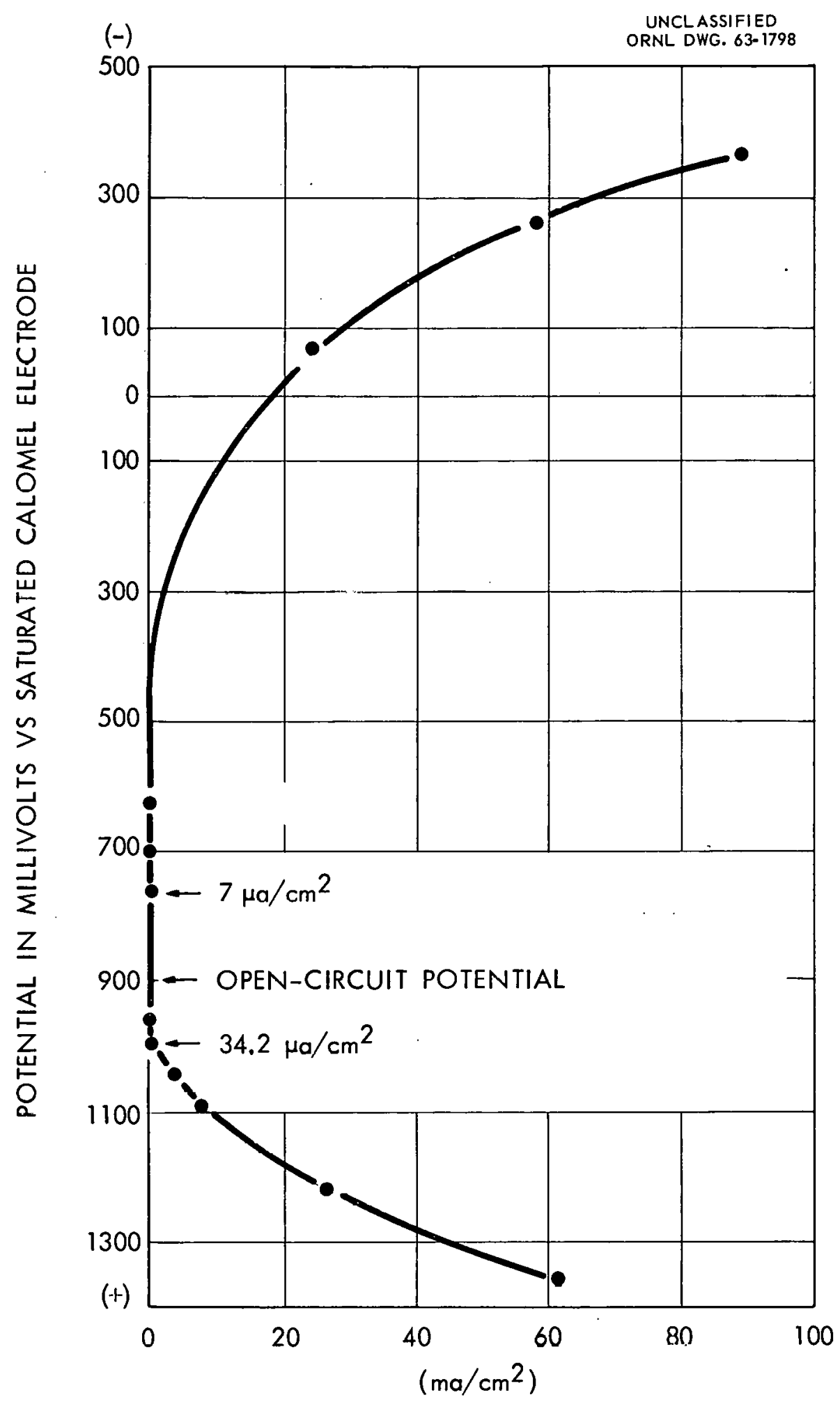

Fig. 14. Polarization of Type $304 \mathrm{~L}$ Stainless Steel at $30^{\circ} \mathrm{C}$ in Simulated Darex-Purex Waste Solution. (5.0 M $\mathrm{HNO}_{3}, 1.82 \mathrm{M} \mathrm{S.S.,} 100$ ppm $\left.\mathrm{Cl}^{-}\right)\left(1 \mathrm{mil} / \mathrm{month} \cong 1002-\mathrm{a} / \mathrm{cm}^{2}\right)$. 


\section{CONCLUSIONS}

Purex raffinates from the reprocessing of stainless steel reactor fuels can be contained in stainless steel tanks without danger of catastrophic corrosion. Low storage temperatures, low acid concentration, and proper fabrication techniques (e.g., the avoiding of end grain exposure) will improve the margin of safety. Use of organic inhibitors may also help, but the production of oxides of nitrogen by radiolysis of the nitrate solution present will probably serve the same purpose. The effect of fission products (e.g., ruthenium) on corrosion has not been determined. Anodic protection of the tank is not feasible; cathodic protection, if practicable, appears unnecessary because of the generation of oxides of . nitrogen by radiolysis. Tanks should be open to the atmosphere to ensure that the air in them does not become depleted in oxygen.

The mechanism of the grain boundary attack has not been adequately investigated, but it has been shown to be caused by the presence of high concentrations of $\mathrm{Fe}$ (III) in the solution. This attack is accelerated in some manner by $\operatorname{Cr}$ (III). Attack due to $F^{\prime}$ (III) has been noted by others.1,3 The presence of even minute concentrations of $\mathrm{Cr}$ (VI) causes accelerated corrosion, which would doubtless develop into true intergranular attack if these concentrations were maintained. The apparent linearity of the plot of the logarithm of the rate vs the reciprocal of the temperature indicates the probability (though it does not prove) that the primary mechanism of attack is the same over the entire temperature range studied.

From a combination of electrode potential and polarization measurements it appears likely that the grain buurdary attack on the steel involves dissolution of chromium as $\mathrm{Cr}$ (VI), which decomposes rapidly in the solution at and below $80^{\circ} \mathrm{C}$. At appreciably higher temperatures any oxides of nitrogen formed will be ariven from the sululion, $\mathrm{Cr}$ (VI) will be stablc, and the corrosion will become much more aggressive. The roles played by $\mathrm{Fe}$ (III) as instigator and by $\mathrm{Cr}$ (III) as accelerator of the corrosion process are not clear. The reason why the corrosion does not develop into true intergranular attack is likewise undetermined. 


\section{ACKNOWLEDGMENT.}

The authors wish to express their indebtedness to A. R. Irvine for suggesting the problem and defining the conditions of storage, and to the members of the ORIVL Metallurgy and Ceramics Division for metallographic studies. 


\section{REFERENCES}

1. E. C. Pitzer, Electrolytic Dissolution of Stainless Steel Clad Fuel Elements, KAPL-653, 1951 (Secret); cf. U. S. Patent No. 2,865,832, June 10, 1953.

2. J. Larsen, R. Barth, N. Sweet, and J. Carter, "Final Report, Subcontract No. 992, Oak Ridge National Laboratory", Carter Laboratories, May 16, 1958.

3. C. M. Slansky, K. L. Rohde, and H. T. Hahn; "Review of Research and Development at the Idaho Chemical Processing Plant on the Electrolytic Dissolution of Nuclear Fuel", IDO-14535, Jan. 19, 1961.

4, A. T. Clark, Jr., L. H. Meyer, J. H. Owen, and F. G. Rust, "Electrolytic Dissolution of Power Reactor Fuels in Nitric Acid", DP-647, Oct. 1961.

5. F.G. Kitts, and W. E. Clark, "Darex Process: Processing of Stainloas Steel-Containing Reactor Fuels with Dilute Aqua Regia", ORNL-2712, May 23,1962.

6. W. D. Bond, "Dissolution of Sintered Thorium-Uranium Oxide Fuel in Nitric Acid-Fluoride Solutions", ORNL-2519, Oct. 28, 1958.

7. I. T. Shirley and J. E. Truman, J. Iron Steel Inst., London 171, 354-8.

8. J. E. Trunar, J. Appl. Chem., 4, 273-83 (May 1954).

9. C. I. Peterson, P. D. Miller, J. D. Jackson, and F. W. Fink, "Construction Materials for Various Head-End Processes for the Aqueous Reprocessing of Spent Fuel Elements", BMI-1375, Aug. 28, 1959, p 85-89; B-7.

10. J. D. Sudbury, O. L. Riggs, Jr., and D. A. Shock, Corrosion, 16, $47 t-54 t(1960)$.

11. J. D. Sudbury, private communication to L. Rice, August 11, 1961.

12. F. A. Posey, private communication to W. E. Clark, Sept. 1962.

13. A. T. Clark, Jr., "Eighteenth Quarterly Progress Report. Jan. 1 to April 1, 1962, Processing of Power Reactor Fuels", DP-740, June 196'.'. 
ORNL- 3474

UC-4 - Chemistry

TID-4500 (22nd ed.)

\section{INTERNAL DISTRIBUTION}

1. Biology Library

2-4. Central Research Library

5. Reactor Division Library

6-7. ORNL - Y-12 Technical Library Document Reference Section

8-4.7. Laboratory Records Departiment

48. Laboratory Records, ORNL R.C.

49. R. E. Blanco

50. J. C. Bresee

51. E. G. Bohlmann

52. G. E. Boyd

53. W. D. Burch

54. F. I. Culler

55. W. E. Clark

56. J. L. English

57. L. G. Farrar

58. H. E. Goeller

59. J. C. Griess

60. D. N. Hess

61. J. M. Holmes
62. M. T. Kelley

63. C. E. Larson

64. H. F. McDuffie

65. A. B. Meservey

66. E. E. Pierce

67. L. Rice

68. M. J. Skinner

69. E. S. Snavely

70. J. A. Swartout

71. H. O. Weeren

72. A. M. Weinberg

73. W. R. Whitson

74. B. Willis

75. J. J. Katz (consultant)

76. P. H. Emmett (consultant)

77. T. H. Pigford (consultant)

78. C. E. Winters (consultant)

79. F. Daniels (consultant)

80. F. T. Gucker (consultant)

81. F. T. Miles (consultant)

\section{EXTERNAL DISTRIBUTION}

82. R. E. Burns, Hanford Atomic Products Operation

83. M. L. Holzworth, Savannah River Laboratory

84. Herbert Katz, Brookhaven National Laboratory

85. P. D. Miller, Battelle Memorial Institute

86. F. G. Rust, Savannah River Laboratory

87. J. T. Roberts, TAEA, Vienna

88. Research and Development Division, AEC, ORO

89-678. Given distribution as shown in TID-4500 (22nd ea.) urider

Chemistry category ( 75 copies - OTS) 